\title{
Higher Education Contexts of Entrepreneurship Education Outcomes in Sub-Saharan Africa
}

\author{
Uchenna Paschal Anosike \\ University of Wolverhampton \\ Stephen Oluwatobi \\ CEO Edustart Global
}

\begin{abstract}
Motivated by the growing emphasis to influence young people's post-study career intentions through entrepreneurship education, particularly in Africa where poverty and conflict have been associated with high youth unemployment, this paper articulates the effect of entrepreneurship education on entrepreneurial intention amongst students and graduates from two higher education institutions in conflict-torn northern Nigeria. By relying on systematic analysis following semi-structured interviews, the findings showed that newly acquired knowledge and skills in use of market intelligence, business plan writing and record-keeping were not only linked with entrepreneurial intentions, but it also emerged that the volatile context of the business environment influenced strategic decisions related to new business growth and survival. Research and policy implications were considered based on the findings.
\end{abstract}

Keywords: entrepreneurship, entrepreneurship education, entrepreneurial intention, new venture creation, conflict, African youths, Sub-Saharan Africa

\section{INTRODUCTION}

Since the mid-1940s, when Harvard University first introduced entrepreneurship education in the higher education sub-sector, the number of higher education institutions offering entrepreneurship education programmes across the world has increased exponentially. Unfortunately, there has been very limited contextual evaluation of such programmes, particularly, how learning strategies in diverse contexts influence the development of entrepreneurial competencies and how these competencies translate into entrepreneurial intention, and ultimately, venture formation (Garavan \& O'Cinneide, 1994). It also remains unclear as to the extent to which entrepreneurship education influences students' entrepreneurial intentionality and behaviour as well as whether it enables students to become more effective entrepreneurs (Pittaway \& Cope, 2007).

However, the main issue is that the current evidence in entrepreneurship education field is heavily dominated and based on insights obtained mainly from stable and predictable learning environments of developed Western economies. Seen from a viewpoint of the rigorous scientific debates that have spawned a vast entrepreneurship education literature, particularly in Europe and the United States, research into how entrepreneurship education influences different entrepreneurial outcomes from the perspective of developing economies is by comparison insignificant. Many studies (e.g. Huang-Saad, Bodnar \& Carberry, 
2020; Gaddefors \& Anderson, 2017; Nabi, Liñán, Fayolle, Krueger \& Walmsley, 2017; Walter \& Block, 2016; Leitch, Hazlett \& Pittaway, 2012) have argued that available evidence in entrepreneurship education research does not provide one with a sufficient intellectual space to understand how entrepreneurship education outcomes are borne out in other relevant contexts.

Moreover, the field of entrepreneurship education research is weighed down by lack of diversity of evidence to advance knowledge and understanding of its boundary-spanning role in different learning environments (Fayolle, Verzat \& Wapshott, 2016, p. 2). Retrospectively, Fayolle (2018) in particular urged researchers to show how entrepreneurship education can be used to produce different set of entrepreneurial outcomes "in a wide range of contexts" (p. 698). This does not imply that existing studies have not produced robust evidence that has enhanced our understanding of entrepreneurship education effectiveness. Learning environments affected by conflict may hold rich boundary-spanning insights vital to broadening our knowledge and understanding of the effectiveness of entrepreneurship education under unstable conditions. What is currently missing is a more inclusive body of evidence from which to undertake a rigorous analysis of the conceptual underpinnings of entrepreneurship education under challenging learning and business environments.

Against this backdrop, this study examined the relationship between entrepreneurship education and students' entrepreneurial intention within the conflict-torn context of northern Nigeria. Generally speaking, studies examining how entrepreneurship education affects different entrepreneurial outcomes either during conflict or in post-conflict environments are very rare, perhaps as a result of the environmental difficulty and hazards associated with obtaining data in these contexts. Notwithstanding, conflict environments present unique and powerful new experimental settings in which to advance research understanding about entrepreneurship in general (see Bruck, Naude \& Verwimp, 2011; 2013; Bruton, Ketchen \& Ireland, 2013; Bruton, Ahlstrom \& Obloj, 2008; Ireland, Reutzel \& Webb, 2005) and entrepreneurial learning in particular (Bullough, Renko \& Myatt, 2013).

Apart from this, the focus on Africa's conflict environment is timely when considered in the wider context of the social and economic upheavals of the COVID-19 pandemic. The pandemic has seen particularly young people in Africa disproportionately affected by soaring unemployment and lack of access to relevant education and training to re-enter employment as businesses reopen. Youth unemployment is the root cause of poverty and together they fuel conflict, which hinders socio-economic progress in Africa. For these reasons, and with only about 3 million of the 10-11 million graduates in Africa accessing decent jobs annually, the most pressing challenge for many governments in the region is to use entrepreneurship education as a mechanism to encourage students and graduates to become self-employed.

In an attempt to address some of these persistent problems given that more than 40 percent of the population are ironically poor in Africa's largest economy, the Nigerian government in particular has placed a greater emphasis on developing educational programmes and schemes that support and encourage young people with the knowledge and skills to start their own business through compulsory entrepreneurship education in the higher education sector. However, the immediate concern is to explore how the medium of entrepreneurship education can foster a set of entrepreneurial competencies amongst a disadvantaged youth population in learning contexts with weak educational infrastructure and failing socio-economic conditions, and exacerbated by the on-going political conflict in northern Nigeria.

Following an entrepreneurship education intervention in two higher education institutions in fragile northern Nigeria, it was found that newly acquired knowledge and skills in analysis of market intelligence and the use of business plans were not only linked with positive entrepreneurial outcomes. Particularly amongst male graduates, but also that the strategic use of market intelligence constituted the vital momentum for the growth and survival of new ventures in the region. Based on these findings, the paper makes two important contributions to entrepreneurship education research. First, evidence from this study has introduced new perspectives that broaden knowledge and understanding of the role of context in the relationship between entrepreneurship education and different entrepreneurial outcomes. This has important pedagogical implications for practice in terms of shaping an understanding of how entrepreneurship education should be designed and taught in schools, particularly in conflict-torn environments of Sub-Saharan Africa (SSA). 
Second, by delineating the boundaries of how the acquisition and use of these skills are directly linked with entrepreneurship education (EE) to influence entrepreneurial intentions, the study supports the idea that certain entrepreneurial skills must be present for entrepreneurial success in any type of business environment-although from the context of a conflict-torn SSA, the use of these skills varies depending on the volatility of the business environment. Thus, in so doing, this study follows an emerging body of EE research that highlights the importance of context in the relationships between entrepreneurship education and different entrepreneurial outcomes (Rauch \& Hulsink, 2015; Elert et al., 2015; Leitch, Hazlett \& Pittaway, 2012; Nabi \& Liñán, 2011).

The rest of the paper is organised as follows: Section Two summarises the extant literature and challenges associated with entrepreneurship education research before providing an analysis of the relationship between entrepreneurship education and different entrepreneurial outcomes in Section Three. Within this section, an attempt is made for the first time to explain the role of context as an important determinant of entrepreneurship education outcomes from the perspective of SSA. Section Four explains the methodological challenges encountered in the course of undertaking this study as well as justification of the methods employed and Section Five presents a synthesis of the findings. The paper concludes with research and policy implications.

\section{ENTREPRENEURSHIP EDUCATION RESEARCH AND CHALLENGES}

Several decades of research interest have witnessed entrepreneurship education evolve in remarkably diverse forms. Much of this interest is centred on entrepreneurship education development (Béchard \& Gregoire, 2005; Kuratko, 2005; Klandt, 2004; Katz, 2003), the characteristics and challenges associated with entrepreneurship education (Hameed \& Irfan, 2019; Kuratko \& Morris, 2018; Greene, Katz \& Johannisson, 2004) and the way in which entrepreneurship education is taught in schools (Fox, Pittaway \& Uzuegbunam, 2018; McMullen \& Dimov, 2013; Fayolle \& Gailly, 2008). Some have examined the relationship between entrepreneurship education and entrepreneurial intentions (e.g. Maresch, Harms, Kailer \& Wimmer-Wurm, 2016; Elert, Andersson \& Wennberg, 2015; Fayolle \& Gailly, 2015; Oosterbeek, van Praag \& Ijsselstein, 2010, Pittaway \& Cope 2007) while others have looked at how entrepreneurship education influences entrepreneurial behaviour (e.g. Nyello, Kalufya, Rengua, Nsolezi \& Ngirwa 2015; Bird, Schjoedt \& Baum, 2012).

Prior studies of entrepreneurship education have categorised entrepreneurial behaviour into four main dimensions-planning, legitimacy, resources and market behaviour-in the firm formation and organising process (Gartner \& Carter, 2003). Factors such as thinking about a business idea, skills in writing a business plan, using market intelligence and forecasting and managing business relationships, which have now emerged as entrepreneurship education outcomes, can be considered as important entrepreneurial attributes in the firm-creation process. The antecedents to these attributes are opportunity recognition and exploitation, which are critical early-stage phenomena of the entrepreneurial process (Shane \& Venkataramam, 2000; Gartner, 1988). Before now, formal and informal education (e.g. university education work experience) and networking have been employed as the human and social capital components used by nascent entrepreneurs for opportunity recognition and exploitation (Dimov, 2017; 2010; Davidsson \& Honig, 2003).

Similarly, various studies have linked entrepreneurship education to human capital outcomes in terms of the skills and knowledge needed for entrepreneurial success. For instance, by integrating the results of previous entrepreneurship education studies, Unger, Rauch, Frese and Rosenbusch (2011) concluded that human capital attributes of knowledge and skills were the educational outcomes that led to entrepreneurial success. Equally, a number of studies (e.g. Anosike, 2019; Martin, McNally \& Kay, 2013; Mosey \& Wright, 2007) have shown that the human capital attributes of skills, training and experience were the outcomes of an entrepreneurship education programme that positively influenced the ability of entrepreneurs to make better business decisions in different environmental contexts. Apart from a human capital perspective, various scholars have highlighted that entrepreneurship education affects the ability of SME ownermanagers to influence the social and economic impact that occurs at organisational and regional levels 
through job creation (e.g. Lindh \& Thorgren, 2016; Schmidt \& Molkentin, 2015; Harrington, 2015; Leitch et al., 2012; Tamásy, 2006; Fritsch \& Mueller, 2004; Armington \& Acs, 2002; Laukkanen, 2000).

More recently, emerging research interest (e.g. Huang-Saad et al., 2020; Gorlewicz \& Jayaram, 2020; Hylton, Miskesell, Yoder \& LeBlanc, 2020; Roy, Schlosser \& Pasek, 2020) explores how to use entrepreneurship education to model science-based and engineering courses in higher education, thereby influencing non-business students to become entrepreneurs. In addition, there are many cross-sectoral examples in innovation-driven countries-including the United States (e.g. Solomon, 2007; Katz, 2003; Solomon, Duffy \& Tarabishy, 2002), Scandinavian countries (e.g. Zaring, Gifford \& McKelvey, 2019; Rasmussen \& Sørheim, 2006) and the United Kingdom - where enterprise education is used alongside entrepreneurship education pedagogies to educate students and small business owners (Jones \& Iredale, 2010; Birdthistle, Hynes \& Fleming, 2007; Raffo, Lovatt, Banks \& O’Connor, 2000).

Despite this broad spectrum of scholarly research, research in entrepreneurship education remains "fragmented" (Fox et al., 2018, p. ). As a consequence, the purpose and role of entrepreneurship education in a wide range of contexts is rendered nebulous (Liguori, Winkler, Winkel, Marvel, Keels, van Gelderen $\&$ Noyes, 2018). This situation makes it difficult to clearly define its boundary with other disciplines with which it overlaps. If anything, educators and higher education practitioners have a hard task identifying the distinct contributions of entrepreneurship education to the broader domains of entrepreneurship, management and education, and precisely what areas of research and practice to focus on (Neck \& Corbett, 2018). These challenges have pedagogical and theoretical implications including whether the emphasis should be on how entrepreneurship education is taught in schools, how entrepreneurship education outcomes should be measured or both (Morris \& Liguori, 2016).

To compound matters, the social and economic roles of entrepreneurship education for individuals and society as well for higher education institutions are yet to be resolved. Coupled with these challenges is the related issue of how entrepreneurship education should be systematised as an instructional tool in higher education institutions, the content and how this content is to be delivered as well as how to structure entrepreneurship education interventions to align with individual and societal needs (Béchard \& Grégoire, 2005). Perhaps, these issues prompted the European Commission to publish in 2013 a comprehensive study (available in 21 languages) intended to serve as a good practice guide on entrepreneurship education for educators and policy makers across Europe ${ }^{1}$. Necessary though it may seem, an entrepreneurship education guide for European educators and practitioners is nonetheless insufficient and does not provide the scope and diversity of evidence needed to advance knowledge and understanding of entrepreneurship education outcomes in different societies.

\section{ENTREPRENEURSHIP EDUCATION OUTCOMES - SUMMARY OF EVIDENCE IN HIGHER EDUCATION}

The existing literature shows positive, negative and inconclusive results in the relationships between entrepreneurship education in higher education and different outcomes. For clarity, in this study, entrepreneurship education outcomes are considered as those phenomena that may arise from one's exposure to entrepreneurship education, which include entrepreneurship awareness, entrepreneurial intentions, entrepreneurial behaviour and new venture formation and management. A meta-analysis of 73 studies by Bae, Qian, Miao and Fiet (2014) yielded mixed results in that they found a significant, although a small, correlation between entrepreneurship education and entrepreneurial intentions among higher education students (henceforward 'students'). But after controlling for pre-education entrepreneurial intentions, they concluded that there was no relationship between entrepreneurship education and posteducation entrepreneurial intentions. In contrast, an analysis of 400 higher education institutions across 70 countries concluded that there was a significant positive relationship between entrepreneurship education and students' entrepreneurial intentions.

By relying on Social Cognitive Career Theory (SCCT) and modified instruments from entrepreneurial intentions (EIs), entrepreneurial self-efficacy (ESE) and entrepreneurial outcome expectations (EOE) concept, Vanevenhoven and Liguori (2013) reported that this positive relationship occurred and remained 
consistent across multiple regions, including in Africa, as students transformed to entrepreneurs. This conclusion mirrors Fayolle, Gailly and Lassas-Clerc (2006) who reported that entrepreneurship education could have a strong positive effect on some students' attitudes towards entrepreneurial behaviour depending on their entrepreneurial experience or level of exposure and awareness of entrepreneurship education. 'Attitude' refers to the extent to which an individual put either a positive or a negative value on his or her ability to become an entrepreneur (Liñán \& Chen, 2009).

Because attitude is about one's perception of having the attributes or capacity to fulfil firm-creation behaviours, it is similar to the idea of self-efficacy originally mooted by Bandura $(1982 ; 1997)$. Regardless of whether or not the business environment is stable, the exposure and awareness of entrepreneurship education could enhance students' perceived entrepreneurial self-efficacy as they journey through further and higher education. This is because there is a perception that exposure to entrepreneurship education helps ease the anxiety often associated with autonomy in the early stages of the firm formation process (Bullough, Renko \& Myatt, 2013). Because autonomy and self-efficacy may be considered as cognates of entrepreneurial attributes, the question that then arises is what constitutes entrepreneurial attributes? How are entrepreneurial attributes linked to entrepreneurship education, particularly in the SSA context?

In examining the relationship between entrepreneurship education and entrepreneurial behaviour of Tanzanian students, Nyello, Kalufya, Rengua, Nsolezi and Ngirwa (2015) provided support for understanding the relationship between entrepreneurship education and entrepreneurial attributes. These attributes were 'need for achievement', 'need for autonomy', 'creativity', 'risk taking', 'drive' and 'determination'. In their case, there were variations in the degree to which entrepreneurship education could be said to have influenced the different entrepreneurial attributes associated with entrepreneurial behaviour. With regard to the need for autonomy, their study revealed that there was a slight difference between higher education graduates who were exposed to entrepreneurship education and those who did not study entrepreneurship. The observed positive difference in the entrepreneurial behaviour attribute of autonomy may be linked to the students' background prior to their study of entrepreneurship.

Notwithstanding, von Graevenitz, Harhoff and Weber (2010, p. 1) found that entrepreneurship education was essential to students" awareness of their "entrepreneurial aptitude" depending on their orientation, motivation and individual circumstance. Whilst exposure to entrepreneurship education seems to be associated with increased antecedents to entrepreneurial behaviour (Fayolle \& Gailly, 2015; Rauch \& Hulsink, 2015; Schmidt \& Molkentin, 2015), the success or failure in the process of new venture creation amongst students was not necessarily associated with entrepreneurship education (Athayde, 2009; Davidsson \& Honig, 2003; Galloway \& Brown, 2002). In contrast, by employing the Theory of Planned Behaviour (TPB), Rauch and Hulsink (2015) found that students that were exposed to entrepreneurship education displayed an "antecedent of entrepreneurial behaviour" closely associated with higher entrepreneurial intentions and new business creation, unlike students that were enrolled in a different programme without the entrepreneurship education component (p. 1). As relevant and as useful as these studies may be, it is obvious that outcomes from entrepreneurship education interventions are not uniform and vary across all contexts.

In their analysis of how entrepreneurship education is experienced in different learning environments, Walter and Dohse (2012) argued that establishing how entrepreneurship education influences different entrepreneurial outcomes across different regional contexts can be difficult to establish. This is because the influence of entrepreneurship education on entrepreneurial outcomes not only varies substantially from individual to individual, but also across institutional and regional levels. In any case, much would depend on how entrepreneurship education is taught in higher education institutions; that is, whether by experiential or active mode (whereby business simulation including business accelerator programmes and incubation are used), by passive mode (whereby only theory and lectures are used), by whom, the learning environment and the specific learning conditions under which individuals encounter entrepreneurship education. Therefore, context seems to be an important factor in establishing the dynamics of the relationship between entrepreneurship education and different entrepreneurial outcomes. Of relevance are learning environments affected by conflict, which may hold unique boundary-spanning insights into entrepreneurship education outcomes very different from stable and conflict-free learning environments. This possibility makes it 
necessary to explore the role of contexts in the entrepreneurship education-entrepreneurial outcomes relationship.

\section{CONTEXT AND ENTREPRENEURSHIP EDUCATION OUTCOMES}

Although much has been written about the relationship between entrepreneurship education and different entrepreneurial outcomes in a wide range of contexts, not much is yet known about how context affects the nature of this relationship. Only very few studies (e.g. Egerová, Eger \& Mičík, 2017; Maresch et al., 2016; Naia et al., 2015; Walter \& Dohse, 2012) have highlighted the importance and relevance of context in analysing the relationships between entrepreneurship education and different entrepreneurial outcomes. To overcome this knowledge gap, and perhaps pave the way for future research, the issues addressed in this section will be primarily concerned with how other contextual factors, i.e. learning conditions and/or the business environment, may interfere and act as a determining influence on people's entrepreneurial propensity and intentionality.

Generating entrepreneurial propensity and intentionality is not a straightforward process that arises merely from teaching entrepreneurship education in schools. Rather, entrepreneurship education outcomes are governed by a combination of powerful and mutually reinforcing contextual dynamics that involve both human and non-human agencies, and several other factors that regulate people's intentions, actions and behaviours at a given time. As Maresch et al. (2016) pointed out, disentangling the various contextual factors (e.g. learning conditions, mode of delivery, instructor) that might produce different entrepreneurship education outcomes even among a specific group of higher education students that have been exposed to entrepreneurship education is a difficult and complex process.

In relation to higher education students, one immediate difficulty relates to determining the actual factors, such as the learning context, the business environment and the socio-economic condition of the learner, that interact with entrepreneurship education to influence post-study entrepreneurial intentions, attitudes and behaviours. Coupled with this is the fact that context, depending on the learning conditions and the nature of the business environment, may either enhance or retard the extent to which entrepreneurship education can be said to influence a particular set of outcomes including entrepreneurial behaviour (Gaddefors \& Anderson, 2017). For instance, learning environments affected by conflict carry a risk of high volatility in the business environment including the possibility of resource scarcity and environmental constraints (e.g. lack of employment), which could threaten the stability of people's livelihoods and force them to make dire entrepreneurial choices. Thus, in such a context, it may be possible to use entrepreneurship education to influence and direct the entrepreneurial intentions or behaviours of those directly or indirectly affected by the conflict.

Because learning is a social process, education targeted at fostering the acquisition of entrepreneurial skills could help facilitate positive entrepreneurship dynamics among different groups in a way that otherwise might not be possible in a conflict context. Evidence has shown that in conflict-affected or even post-conflict contexts with on-going social and economic upheavals, entrepreneurship activity has helped to increase pro-social behaviour, resolve in-group dilemmas and minimise hostility and conflictual group relationships in those environments. For instance, in an analysis of entrepreneurial skills and opportunities for youth start-up creation, Brixiová, Ncube and Bicaba (2015) found that entrepreneurial training enhanced positive intergroup interaction between adult and young nascent entrepreneurs in a post-Apartheid Swaziland. Similarly, Honig (2001) used the situation in the West Bank and Gaza to demonstrate that small business owners rather than large firms actually benefit most from formal entrepreneurial education and training during periods of economic shock caused by political conflict.

However, in conflict-torn and post-conflict learning environments, the main challenge for higher education practitioners is not education provision per se, but the ability to modify and adapt learning pedagogies and contents in such a way that they satisfy both the specific and varied needs of learners in

those contexts. Adapting entrepreneurship education programmes and delivery modes to suit the needs of specific learner communities in conflict and post-conflict environments must therefore be the primary focus for educators. This is because learner communities in conflict-torn or post-conflict environments have 
unique and sometimes rapidly changing needs (e.g. the psychological trauma of conflict may interfere with their cognitive ability), which may be different from learners in contexts where the learning environment is stable and more predictable. However, "as a contextually determined concept", entrepreneurship education could be modified to meet the specific needs of particular learner groups regardless of the environmental constraints (Egerová et al., 2017, p. 1). This implies that the design, delivery and evaluation of entrepreneurship education "cannot be viewed as a one size fits all" (Wilson, Kickul \& Marlino, 2007, p. 400). If this is the case, then in contexts in which learning conditions are affected by conflict, it makes sense to customise entrepreneurship education so that it takes into account the context-specific needs of learners in that context (Naia et al., 2015; van der Sluis, van Praag \& Vijverberg, 2005).

Customisation of entrepreneurship education programmes is more likely than not to reduce the complications associated with establishing the specific entrepreneurial outcomes that may arise from entrepreneurship education intervention. This assumption is especially relevant to contexts that are particularly prone to resource scarcity and environmental constraints, such as in northern Nigeria, where mass youth unemployment and poverty have led to violence and young people's vulnerability to the political conflict led by the Boko Haram Islamist group (Usman, 2009). To a large extent, scarcity of resources in any learning context, not just in Nigeria, generally makes learning and education provision particularly challenging. In addition, conflict environments have the potential to reduce the ability of individuals to develop the cognitive competencies needed to recognise and exploit opportunities. Hence, there is a possibility that learners in such challenging environments may be more motivated by a greater need for survival rather than for profit motives in an entrepreneurial sense.

As an idea, opportunity recognition and exploitation in an entrepreneurial sense is closely associated with the Schumpeterian notion of entrepreneurship, whereby the attraction of disruptive and high-value innovation pulls the individual into seeking and exploiting opportunity for profit motives (Bird, Schjoedt $\&$ Baum, 2012). By contrast, when faced with the need to respond to an immediate and persistent social and economic threat (e.g. resource scarcity and environmental constraint) such as in northern Nigeria, where people's livelihoods are devastated by conflict, individuals are far more likely than not to exhibit survivalist entrepreneurial tendency in an attempt to respond to the threat regardless of the nature of learning interventions. Put differently, the idea of survivalist entrepreneurship is in many ways associated with the concept of "entrepreneurial bricolage" (Davidsson, Baker \& Senyard, 2017), which explains how individuals utilise the resources at hand in the midst of environmental and resource constraints (Baker \& Nelson, 2005).

To sum up, regardless of the learning interventions, it seems logical to argue that people's propensity and intention to engage in an entrepreneurship activity are either opportunity- or necessity-driven, depending on their needs and circumstances, whereas people in learning environments affected by conflict may be influenced, through the medium of entrepreneurship education, to exhibit entrepreneurial intention. Equally and paradoxically, it is possible that entrepreneurial intention may not arise merely as a result of exposure to entrepreneurship education, but is also influenced by other contextual factors (e.g. survival instinct) unrelated to entrepreneurship education.

\section{METHODOLOGY}

Evaluating the effect of entrepreneurship education on students' post-study intentions in any learning environment affected by conflict will inevitably present some methodological challenges. These challenges will vary in relation to the dynamics of the research environment and the motivations of the researcher. In the course of undertaking this study, some challenges were encountered given the political conflict in northern Nigeria. First, for people's safety, travel restrictions to the conflict area made it somewhat difficult to work closely with educators to recruit participants. Second, the stress, anxiety and the psychological trauma that came with the political conflict in the region limited the ability of participants to fully articulate the effect of the learning intervention on their post-learning career motivations.

In some cases, the conflict caused some participants to abandon their participation in learning, thereby making it difficult for them to share their experiences. However, a series of interventions were devised to 
tackle these challenges. Because the sampled population belonged to closely-knit communities, it was possible to rely on personal networks to recruit participants. Second, to incentivise and sustain participation during data collection, group-based social activities (e.g. puzzle games) were organised to keep participants engaged. These strategies had a positive influence on participants' disposition and psychological wellbeing through the three-month data collection period.

Against this backdrop, the snowball sampling technique was used to contact several students and graduates of two federal universities in northern Nigeria who took part in an entrepreneurship education intervention programme implemented as part of a wider effort to tackle youth unemployment and poverty in the region. Out of the 25 potential participants contacted, 10 fully participated in this study. Consistent with previous studies (e.g. Bullough et al., 2014) undertaken within conflict or post-conflict environments, and by following strict confidentiality protocol, data were collected using exploratory interviews. Given that some of the participants were still dealing with the psychological trauma of loss and devastation, semistructured interviews were very effective in gathering their experiences throughout the intervention period. Altogether, the interviews lasted for 35 minutes on average and were audio-recorded and transcribed verbatim.

Following previous studies (e.g. Souitaris, Zerbinati \& Al-Laham, 2007), participants were asked questions related to their learning experiences, employment status, income level and their business planning and market analytic skills as well as whether or not they had used these skills prior to and following their participation in the entrepreneurship education programme. Participants were asked also whether or not they had been influenced to start their own business as a result of their experience of the entrepreneurship education programme. Finally, the participants were invited to provide information related to their business including their use of knowledge and skills either before or after the programme. To protect their identities, their names have been anonymised and designated as P1-P10. Preliminary insights from the interviews are presented below using thematic analysis.

\section{ANALYSIS AND SUMMARY OF FINDINGS}

Sub-themes such as 'business plan writing', 'analysis of market intelligence', 'managing relationships' and 'record keeping' were frequently used to define the knowledge and skills acquired from entrepreneurship education, which in many ways influenced participants' firm-creation behaviours. In summing up their overall experience, P1 affirmed: "Before the entrepreneurship programme, I did not have much knowledge about business. After the entrepreneurship education training, I know better how to plan and invest my money. I know better now how to deal with companies who supply our goods".

It seemed that participants perceived that they have increased their self-confidence, particularly in relation to recognition and exploitation of opportunities in a conflict-torn business environment. For instance, knowledge and skills in the analysis of market intelligence were deployed effectively to justify strategic and future business decisions, thus:

"I supply and sell cold drinks in Maiduguri. In the next three or four years, because of the insurgency in the city, I want to open new branches in Kano, in Yobe. I will have another in maybe Bauchi, which is somewhat further away. I hope to employ like 50 more people in the next four years. I have also visited some places in Jigawa and I can see it is especially hot at some points of the year, so it is a very good place to sell cold drinks" (P8).

This resonates with Bruck, Naude and Verwimp (2013) who found that conflict contexts may either create or hinder the opportunity to take risks or exploit the opportunity created by the conflict. As important social dimensions to the early features of the entrepreneurial process, opportunity recognition and exploitation are associated with the human capital components of education, knowledge and skills (Unger et al., 2011; Dimov, 2010). Thus, it was obvious that the decision to take advantage of opportunities presented elsewhere was directly linked to the participant's knowledge and ability to use market intelligence to assess the business environment and make strategic business choices. 
However, reference to the "insurgency" illustrates that strategic business choices that may affect the success and growth of new ventures could also be influenced by contextual factors unrelated to the knowledge and skills gained from the entrepreneurship education. Thus, the entrepreneurial attribute of good decision-making skills exhibited by P8 may not have been as a direct result of his exposure to entrepreneurship training per se. Given the perceived challenges presented by the conflict in Maiduguri, the decision by P8 to expand his business could be more because of survival instinct than entrepreneurship education. This is consistent with other studies in the field (e.g. Athayde, 2009; Davidsson \& Honig, 2003; Galloway \& Brown, 2002), which found that the success of new ventures was not always associated with exposure to entrepreneurship education.

But more importantly, the use of market intelligence as a basis to exploit business opportunities is closely linked with the idea of entrepreneurial self-efficacy. Self-efficacy is an inherent psychological trait that allows an individual to persist, even in the face of obstacles, on a particular course of action he or she may deem as beneficial. In his widely cited analysis of the self-efficacy mechanism of human agency, Bandura (1982, p. 123) argued that when faced with challenges, people with "serious self-doubts about their capabilities" tend to reduce their efforts or "give up altogether", whereas those with a "strong sense of self-efficacy show greater effort" in confronting those challenges. By wishing to set up his own IT business despite the challenges, it would seem that P8, along with other participants who showed interest in starting their own business, displayed entrepreneurial self-efficacy:

"I am a computer engineer, so I hope to set up an IT centre... an authorised HP centre where I will render repairs and maintenance services for laptops, desktops and so on" (P7).

However, an important feature of this study is that male participants in resource-poor northern Nigeria were found to have developed a much stronger inclination towards business planning skills for venture creation. Thus, they exhibited a heightened sense of self-efficacy belief compared to their female counterparts. By contrast, Wilson et al. (2007) reported that in resource-rich developed market economies, the effect of entrepreneurship education on entrepreneurial self-efficacy proved much stronger for women than for men.

Notwithstanding, as Drnovšek, Vincent and Cardon (2010) implied, the apparent strong sense of selfefficacy amongst male participants clearly may have been borne out of their involvement in the entrepreneurship education programme and perhaps equates to the strength of their entrepreneurial intention as seen in their desires to alter their poor social and economic conditions through starting their own business. As such and similar to Jones, Penaluna and Pittaway (2014), these perceptions are the strongest evidence yet and reinforce the notion that entrepreneurship education may be a recipe for social and economic change. In addition, based on the determination of P7 to start his own IT business, this study begins to respond to the concern raised by Béchard and Grégoire (2005) that the social and economic role of entrepreneurship education for the individual and the society was not yet clear.

This strong sense of self-efficacy is true for another participant who perceived that he "benefited a lot from the entrepreneurship programme in terms of business planning skills" and will "plan to start a transport business" (P3). Emerging also from the interviews is a more acute sense of entrepreneurial knowledge acquisition and how to apply this knowledge in the context of an entrepreneurial pursuit. Thus, as another participant stated: "One of the main lessons I learnt was writing a good business plan. With the format they gave, I was surprised by how much I was able to write" (P6). Another participant perceived that: "From the entrepreneurship training I knew that I had to keep records about my inflows and outflows" (P2). These findings resonate with Honig (2004, p. 258), which reported that exposure to entrepreneurship education, particularly those that provide practical business planning experience, "increases individual self-reported intentions to begin a business". In addition, record-keeping is especially relevant to the Nigerian SME context, as the majority of micro and small business operators rarely keep financial records. Apart from poor record-keeping, many find it difficult to separate their business expenditure from their household expenditure, thereby preventing access to bank loans essential to the survival and growth of new businesses. 
From the participants' experiences, their general perception is that: "With entrepreneurship education, people will learn to do things for themselves so they won't be idle or rely on the government any longer" (P10). The perception was that if young people, especially the unemployed, were better educated in entrepreneurship, then the idea of "fighting illegal war against the government" may not exist (P5). Clearly, these are powerful instances which show that empowering young people and women to start their own business through the medium of entrepreneurship education, may be vital to winning the fight against youth unemployment, poverty and conflict in SSA. This view is shared by Ojeifo (2013) and Nwabufo and Mamman (2015), suggests that entrepreneurship education could be a useful mechanism for bringing about economic empowerment and peaceful co-existence amongst Nigerian youths. Similar conclusions were drawn by Brixiova et al. (2015) in the post-conflict contexts of Southern Africa.

Participants also believe that many women who have lost their husbands or male providers as a direct result of the conflict could become economically self-sustaining through exposure to entrepreneurship education; thus:

I think the Boko Haram insurgency has really affected all of society, especially women. There are more single parents now due to the insurgency. Many women who were dependent now have to be independent, and they don't have the support and training to even do business planning, analyse the environment and fend for themselves. I think the entrepreneurship training can be designed in a way to train more women who can actually help to train others. The religious culture here, you know, stops women from doing a lot of things and working with others (P2).

The perception that entrepreneurship education, if modified and targeted, may be used to empower women adversely affected by conflict, is a sentiment shared by other studies (e.g. Egerová et al., 2017; Naia et al., 2015; van der Sluis et al., 2005), which argue that entrepreneurship education can be modified to meet the specific needs of particular learner groups regardless of the environmental constraints.

However, as earlier mentioned, the perceived sense of entrepreneurial self-efficacy among male participants was not immediately obvious among their female counterparts. This finding presents a particular challenge and is comparable to Demirgüc-Kunt et al. (2011) and van der Sluis et al. (2005), which found that survival is a strong entrepreneurial attribute amongst male entrepreneurs operating in challenging environments in developing economies. Thus, it may be that the set of knowledge, skills and entrepreneurial competences that women entrepreneurs need (e.g. analytical, problem-solving, teamworking and networking skills) in order to survive in a conflict-torn business environment is perhaps broader in scope than, for example, business planning and analysis of market intelligence.

If this is the case, then it may be useful to modify entrepreneurship education by integrating learning processes that produce analytical, team-working and networking skills as a way of increasing the odds of women's learning and entrepreneurial success in a conflict environment. This is particularly relevant to the context of northern Nigeria and other African societies where entrenched patrilineal norms (e.g. early and forced marriage) used to perpetuate a cycle of female dependence on a male provider prevent women from achieving entrepreneurial success (Makama, 2013; Takyi-Asiedu, 1993). This finding brings contextual clarity to how entrepreneurship education, through appropriate content, design and pedagogy, could be systematised to influence beneficial social and economic outcomes for distinct groups of women.

\section{RESEARCH AND POLICY IMPLICATIONS}

Among the broad spectrum of theoretical and conceptual limitations facing research in state-of-the-art entrepreneurship education, of interest are three pressing concerns: a lack of inclusive evidence to show the social and economic role of entrepreneurship education for individuals and society, systemisation of entrepreneurship education and how it is to be delivered in conflict settings as well as how to structure entrepreneurship education to align with the specific needs of certain learner communities. This study addresses these concerns through a situated analysis of the socio-economic challenges facing Africa's 
growing youth population. Through the findings, it highlights implications for young people's productivity through the medium of entrepreneurship education and, subsequently, explored its effect on their entrepreneurial intentions within the contexts of learning and business environments affected by the political conflict in northern Nigeria. In demonstrating these connections, the study advances understanding of how context has emerged as an important, although often neglected factor in determining the relationship between entrepreneurship education and entrepreneurial intentions.

First, by introducing the conflict context of SSA, this study begins to articulate the role of entrepreneurship education in providing individuals and the wider society affected by the conflict with social and economic benefits in form of knowledge and skills for self-employment. Intuitively, because of the obvious institutional obstacles that limit the ability of the labour market to absorb many young graduates in Africa, the priority must be to encourage the development of entrepreneurial competencies through creating the social conditions in education and training that can allow young people to acquire varying human capital competencies for self-sufficiency. The acquisition of these competencies through the medium of entrepreneurship education has been found to lead to success in the early stages of the entrepreneurial process (Ulvenblad, Berggren \& Winborg, 2011).

Specifically, the ability to use market intelligence was closely linked with entrepreneurial self-efficacy, which was deployed in the context of opportunity identification and exploitation heightened by the conflict. As an innate psychological state that enables the individual to persist on a particular course of action even in the face of unforeseen obstacles (Wilson et al., 2007; Drnovšek et al., 2010; Bandura, 1982), entrepreneurial self-efficacy emerged in this study as a useful mechanism that can be used to influence students and graduates to at least consider entrepreneurship as a career after their study. As such, this study provides some unique insights into the social role and benefit of entrepreneurship education as a vehicle to influence young people's post-study entrepreneurial intentions.

Because the conflict context of SSA is an evolving experimental setting to broaden entrepreneurship education research, the implicit reference to entrepreneurial self-efficacy as a resource for the identification and exploitation of opportunity offers several implications for future research. Future studies could evaluate the entrepreneurship education programmes that produce social and economic value for certain population groups, the nature and various manifestations of this value and why these may not create similar value for others such as women. For instance, research could focus on understanding the specific ways in which entrepreneurship education contents and pedagogies could be systematised and used to address the specific educational needs of female learners and female entrepreneurs as a disadvantaged group. Perhaps, an emphasis on entrepreneurship education programme that enhances analytical, problem-solving and teamworking skills as well as provide opportunities for networking may help to increase women's entrepreneurial self-efficacy in a way similar to their male counterparts.

In addition, future research could consider a more in-depth statistical analysis of the correlates of entrepreneurship education contents and pedagogies that underlie the positive effect on young people's entrepreneurial intentions by including other variables to control for rival explanations beyond the current emphasis on market intelligence, market analysis skills and use of business plans. The importance of introducing other variables may help the replication of this study in other regional settings and contexts where entrepreneurship education is not necessarily at the centre of national educational efforts to provide young people with the knowledge and skills for self-employment.

One example would be a cross-sectional study that seeks to reveal the relative or comparable value (or lack thereof) of the effectiveness of entrepreneurship education in comparison to other educational initiatives aimed at providing young people with knowledge and skills for employment, such as Technical Vocational Education and Training ${ }^{2}$ (TVET), which is particularly prevalent in Eastern Africa. A study of this nature is useful given that political conflict remains a common feature of both Western and Eastern Africa. As such, both regions offer comparably favourable contexts in which to assess, in a cross-sectional analysis, the interdependences between various contextual factors (e.g. poverty, high youth unemployment) that determine people's propensity towards entrepreneurship and how these factors play out in relation to entrepreneurship education, human capital and firm-creation intentions. 
From a policy standpoint, several possibilities emerge from this study. First, radical reforms of Africa's educational systems are vital. Of immediate concern is prioritising investment in educational programmes that create the conditions for young people to successfully open and run their own business. It also requires putting in place the conditions that increase women's participation in entrepreneurship education programmes as a way to provide them with access to the relevant knowledge and skills needed for selfemployment. Given the prevalence of patriarchal norms in many parts of northern Nigeria, increased investment in entrepreneurship education will help empower women and thereby reduce their dependence on a male provider, and the economic hardship and poverty that may result from the loss of that male provider.

Second, following Zanello (2016) and related to the previous point, this study sheds further light on the need to take into account gender issues in the design and delivery of entrepreneurship education. Rather than solely focus on developing an entrepreneurial mind-set and the capabilities for entrepreneurial success, perhaps policy makers should consider how national education policies can be designed so as to make entrepreneurship education programmes more inclusive and, where necessary, modified to tackle the specific barriers women face as nascent entrepreneurs. This is important in the broader context of the fact that more and more women-owned enterprises have now become vital sources of household income in Africa (Nichter \& Goldmark, 2009).

However, from a practical viewpoint, reviewing national policies to align with the needs of certain population groups may be problematic given that such national policies are prone to frequent change and their impact is rarely monitored in the Nigerian context. Therefore, it may be more sensible to directly empower education providers and teachers with the necessary tools and skills required to design their entrepreneurship education curricula to accommodate the nuanced needs of aspiring women entrepreneurs. This is important given the reported gender differences in access to the knowledge and skills for business planning and analytical skills. Other ways in which the challenge could be tackled in the SSA context might be to introduce and integrate practice-based and action-oriented gender-sensitive topics, such as networking skills, confidence building measures and work-life balance into tertiary-level entrepreneurship education programmes. Integrating action-oriented learning philosophy into the entrepreneurship education curriculum is more likely to stimulate entrepreneurial drive, boost entrepreneurial self-efficacy and, consequently, the likelihood of new business formation and success amongst women.

\section{CONCLUSION}

Much of the previous research emphasised specific elements of entrepreneurship education and the pedagogical processes that influenced certain entrepreneurial outcomes as well as the attributes and attitudes of nascent entrepreneurs without considering how the learning and business contexts influenced these outcomes. In this study, the conflict context of northern Nigerian was used as an experimental context in which to demonstrate how a challenging environment, in addition to entrepreneurship education intervention, provided individuals with the incentive to engage in an entrepreneurship activity. Given that this study relied on a sample from SSA region, it is important to be cautious in generalising its findings to other contexts. Notwithstanding, proper systematisation of entrepreneurship education programmes in any conflict environment can influence positive and beneficial outcomes for learners.

By providing social and economic benefits through provision of access to livelihood opportunities needed for economic growth in Africa, entrepreneurship education has been shown to increase young people's knowledge and productivity. To achieve economic growth through young people's productivity, policy makers, governments and higher education providers must work together to foster learning conditions under which young people can acquire the necessary knowledge, skills and creativity to pursue a career as entrepreneurs, and thereby create economic opportunities for themselves and benefit the wider society through job creation. 


\section{ENDNOTES}

1. See the report published by the Entrepreneurship 2020 Unit Directorate-General for Enterprise and Industry, European Commission entitled: Entrepreneurship Education: A Guide for Educators available via: https://www.schooleducationgateway.eu/en/pub/resources/publications/entrepreneurship-education---a.htm

2. Technical Vocational Education and Training (TVET) is a learning activity common in SSA that provides knowledge, skills, attitudes and training relevant for employment and self-employment.

\section{REFERENCES}

Anosike, U.P. (2019). Entrepreneurship education as human capital: Implications for youth selfemployment and conflict mitigation in sub-Saharan Africa. Industry \& Higher Education, 33(1), $42-54$

Armington, C., \& Acs, Z. (2002). The determinants of regional variation in new firm formation. Regional Studies, 36, 33-45.

Athayde, R. (2009). Measuring enterprise potential in young people. Entrepreneurship Theory and Practice, 33(2), 481-500.

Bae, T.J., Qian, S., Miao, C., \& Fiet, J.O. (2014). The Relationship Between Entrepreneurship Education and Entrepreneurial Intentions: A Meta-Analytic Review. Entrepreneurship: Theory \& Practice, $38(2), 217-254$

Baker, T., \& Nelson, R. (2005). Creating something from nothing: resource construction through entrepreneurial bricolage. Administrative Science Qaurterly, 50(3), 319-366

Bandura, A. (1982). Self-efficacy mechanism in human agency. American Psychologist, 37(2), 122-147.

Bandura, A. (1997). Self-efficacy: The exercise of control. New York: Freeman.

Béchard, J., \& Grégoire, D.A. (2005). Entrepreneurship education research revisited: the case of higher education. Academy of Management Learning and Education, 4(1), 22-43.

Bird, B., Schjoedt, L., \& Baum, J.R. (2012). Editor's Introduction. Entrepreneurs' Behavior: Elucidation and Measurement. Entrepreneurship Theory and Practice, 36(5), 889-913.

Birdthistle, N., Hynes, B., \& Fleming, P. (2007). Enterprise education programmes in secondary school in Ireland: a multi-stakeholder perspective. Education and Training, 49(4), 265-276.

Brixiová, Z., Ncube, M., \& Bicaba, Z. (2015, March). Skills and Youth Entrepreneurship in Africa: Analysis with Evidence from Swaziland. World Development, 67, 11-26.

Bruck, T., Naude, W., \& Verwimp, P. (2011). Small business, entrepreneurship and violent conflict in developing countries. Journal of Small Business and Entrepreneurship, 24(2), 161-178.

Bruck, T., Naude, W., \& Verwimp, P. (2013). Business under fire: Entrepreneurship and violent conflict in developing countries. Journal of Conflict Resolution, 57(1), 3-19.

Bruton, G., Ketchen, D., \& Ireland. (2013). Entrepreneurship as a solution to poverty. Journal of Business Venturing, 28(6), 683-689.

Bruton, G., Ahlstrom, D., \& Obloj, K. (2008). Entrepreneurship in emerging economies: Where are we today and where should the research go in the future. Entrepreneurship Theory and Practice, $32(1), 1-14$.

Bullough, A., Renko, M., \& Myatt, T. (2013). Danger zone entrepreneurs: The importance of resilience and self-efficacy for entrepreneurial intentions. Entrepreneurship Theory and Practice, 38(3), 473-499.

Davidsson, P., \& Honig, B. (2003). The role of social and human capital among nascent entrepreneurs. Journal of Business Venturing, 18(3), 301-331.

Davidsson, P., Baker, T., \& Senyard, J. (2017). A measure of entrepreneurial bricolage behaviour. International Journal of Entrepreneurial Behaviour and Research, 23(1), 114-135.

Demirguc-Kunt, A., Klapper, L., \& Panos, G. (2011). Entrepreneurship in post-conflict transition. Economics of Transition, 19(1), 27-78. 
Dimov, D. (2017). Towards a qualitative understanding of human capital and entrepreneurship research. International Journal of Entrepreneurial Behaviour and Research, 23(2), 210-227.

Drnovšek, M., Wincent, J., \& Cardon, M. (2010). Entrepreneurial self-efficacy and business start-up: Developing a multi-dimensional definition. International Journal of Entrepreneurial Behaviour and Research, 16(4), 329-328.

Egerová, D., Eger, L., \& Mičík, M. (2017). Does entrepreneurship education matter? Business students' perspectives. Tertiary Education and Management, 23(4) 1-15.

Elert, N., Andersson, F., \& Wennberg, K. (2015). The impact of entrepreneurship education in high school on long-term entrepreneurial performance. Journal of Economic Behaviour and Organization, $111(\mathrm{c}), 209-223$.

Fayolle, A. (2013). Personal views on the future of entrepreneurship education. Entrepreneurship and Regional Development, 25(7-8), 692-701.

Fayolle, A. (2018). A research agenda for entrepreneurship education. Cheltenham, UK: Edward Elgar Publishing.

Fayolle, A., \& Gailly, B. (2008). From craft to science: Teaching models and learning processes in entrepreneurship education. Journal of European Industrial Training, 32(7), 569-593.

Fayolle, A., \& Gailly, B. (2015). The impact of entrepreneurial education on entrepreneurial attitudes and intention: Hysteresis and persistence. Journal of Small Business Management, 53(1), 75-93

Fayolle,.A., Gailly, B., \& Lassas-Clerc, N. (2006). Assessing the impact of entrepreneurship education programmes: A new methodology. Journal of European Industrial Training, 30(9), 701-720.

Fayolle, A., Verzat, C., \& Wapshott, R. (2016). In Quest of Legitimacy: The Theoretical and Methodological Foundations of Entrepreneurship Education Research. International Small Business Journal, 34(7), 895-904.

Fox, J., Pittaway, L., \& Uzuegbunam, I. (2018). Simulations in entrepreneurship education: Serious games and learning through play. Entrepreneurship Education and Pedagogy, 1(1), 61-89.

Fritsch, M., \& Mueller, P. (2004). Effects of new business formation or regional development over time. Regional Studies, 38(8), 961-975.

Gaddefors, J., \& Anderson, A. (2017). Entrepreneurship and context: when entrepreneurship is greater than entrepreneurs. International Journal of Entrepreneurial Behaviour and Research, 23(2), 267-278.

Galloway, L., \& Brown, W. (2002). Entrepreneurship education at university: A driver in the creation of high growth firms. Education + Training, 44(8/9), 398-405.

Garavan, T.N., \& O’Cinneide, B. (1994). Entrepreneurship educaiotn and traiing programmes: A review and evaluation - Part 1. Journal of European Industrial Training, 18(8), 3-12.

Gartner, W.B. (1988). Who is an entrepreneur? Is the wrong question. American Journal of Small Business, 12(4), 11-32

Gartner, W.B., \& Carter, N.M. (2003). Entrepreneurial behaviour and firm organising processes. In Z.J. Acs \& D.B. Audretsch (Eds.), Handbook of entrepreneurship research (pp. 195-221). New York: Kluwer Academic Publishers

Gorlewicz, J.L., \& Jayaram, S. (2020). Instilling Curiosity, Connections and Creating Value in Entrepreneurial Minded Engineering: Concepts for a course sequence in dynamics and controls. Entrepreneurship Education and Pedagogy, 3, 60-85

Greene, P., Katz, J., \& Johannisson, B. (2004). From the guest co-editors: entrepreneurship education. Academy of Management Learning and Education, 3(3), 238-241.

Hameed, I., \& Irfan, Z. (2019). Entreprenuership education: A review of challenges, characteristics and opportunities. Entreprenuership Education, 2(3-4), 135-148.

Honig, B. (2001). Learning strategies and resources for entreprenuers and intrapreneurs. Entreprenuership Theory and Practice, 26(1), 21-34.

Honig, B. (2004). Entreprenuership education: toward a model of contingency-based business planning. Academy of Management Learning and Education, 3(3), 258-273. 
Huang-Saad, A., Bodnar, C., \& Carberry, A. (2020) Examining current practices in engineering entrepreneurship education. Entrepreneurship Education and Pedagogy, 3(1), 4-13.

Ireland, R.D., Reutzel, C.R., \& Webb, J.W. (2005). Entreprenuership research in AMJ: What has been published, and what might the futre hold? Academy of Management Journal, 48(4), 556-564.

Jones, B., \& Iredale, N. (2010). Enterprise education as pedagogy. Education and Training, 52(1), 7-19.

Jones, P., Penaluna, A., \& Pittaway, L. (2014). Entrepreneurship education: A recipe for change. International Journal of Management Education, 12(3), 304-306.

Katz, J.A. (2003). The chronology and intellectual trajectory of American entrepreneurship education. Journal of Business Venturing, 18(2), 283-300.

Klandt, H. (2004). Entrepreneurship Education and Research in German-Speaking Europe. Academy of Management Learning \& Education, 3(3), 293-301.

Kuratko, D. (2005). The emergence of entrepreneurship education: Development, trends and challenges. Entrepreneurship Theory and Practice. 29(5), 577-598.

Kuratko, D., \& Morris, H. (2018). Corporate entreprenuership: A critical challenge for educators and researchers. Entreprenuership Education Pedagogy, 1(1), 42-60.

Laukkanen, M. (2000). Exploring alternative approaches in high -level entrepreneurship education: Creating micromechanisms for endogenous regional growth. Entrepreneurship and Regional Development, 12(1), 1-23.

Leitch, C., Hazlett, S., \& Pittaway, L. (2012). Entrepreneurship education and context. Entrepreneurship and Regional Development, 24(9-10), 733-740.

Liguori, E., Winkler, C., Winkel, D., Marvel, M., Keels, J., van Gelderen, M., \& Noyes, E. (2018). Entrepreneurship education imperative: Introducing EE\&P. Entrepreneurship Education and Pedagogy, l(1), 5-7.

Liñán, F., \& Chen, Y. (2009). Development and cross-cultural application of a specific instrument to measure entrepreneurial intentions. Entrepreneurship Theory and Practice, 33(3), 593-617

Lindh, I., \& Thorgren, S. (2016). Entrepreneurship education: The role of local business. Entrepreneurship and Regional Development, 28(5-6), 313-336.

Makama, G.A. (2013). Patriarchy and gender inequality in Nigeria: The way forward. European Scientific Journal, 9(17), 1857-7881.

Maresch, D., Harms, R., Kailer, N., \& Wimmer-Wurm, B. (2016). The impact of entrepreneurship education on the entrepreneurial intentions of students in the science and engineering versus business studies university programs. Technological Forecasting and Social Change, 104, 172179.

Martin, B.C., McNally, J.J., \& Kay, M.J. (2013). Examining the formation of human capital in entreprenuership: A meta-analysis of entreprenuership education outcomes. Journal of Business Venturing, 28, 211-224.

McMullen, J.S., \& Dimov, D. (2013). Time and the entrepreneurial journey: The problems and promise of studyng entreprenuership as a process. Journal of Management, 50(8), 1481-1512.

Morris, M.H., \& Ligouri, E. (2016). Preface: Teaching reason and unreasonable. In M.H. Morris \& E. Ligouri (Eds.), Annals of Entrepreneurship Education and Pedagogy (pp. xiv-xxii).

Northampton, MA: Edward Elgar Publishing.

Mosey, S., \& Wright, M. (2007). From human capital to social capital: A longitudinal study of technologybased academic entrepreneurs. Entrepreneurship Theory and Practice, 31(6), 909-935.

Nabi, G., Liñán, F., Fayolle, A., Krueger, N., \& Walmsley, A. (2017). The Impact of Entrepreneurship Education in higher Education: A Systematic Review and Research Agenda. Academy of Management Learning \& Education, 16(2), 277-299.

Nabi, G., \& Liñán, F. (2011). Graduate entrepreneurship in the developing world: intentions, education and development. Education + Training, 53(5), 325-334.

Neck, H.M., \& Corbett, A.C. (2018). The scholarship of teaching and learning entreprenuership. Entrepreneurship Education Pedagogy, 1(1), 8-41. 
Nichter, S., \& Goldmark, L. (2009). Small firm growth in developing countries. World Development, 37(9), 1453-1464.

Nwabufo, N., \& Mamman, J (2015). Entrepreneurship education: A panacea for curbing graduate unemployment in Nigeria. International Journal of Teaching and Education, III(3), 68-74

Nyello, R., Kalufya, N., Rengua, C., Nsolezi, M., \& Ngirwa, C. (2015). Entreprenuership education on entrepreneurial behaviour: The case of graduates in the higher learning institutions in Tanzania. Asian Journal of Business Management, 7(2), 37- 42.

O'Connor, A. (2013). A conceptual framework for entrepreneurship education policy: Meeting government and economic purposes. Journal of Business Venturing, 28, 546-563.

Ojeifo, S.A. (2013). Entrepreneurship education in Nigeria: a panacea for youth unemployment. Journal of Education and Practice, 4(6), 61-66.

Oosterbeek, H., van Praag, M., \& Ijsselstein, A. (2010). The impact of entrepreneurship education on entrepreneurship skills and motivation. European Economic Review, 54, 442-454.

Pittaway, L., \& Cope, J. (2007), Entrepreneurship education: A systematic review of the evidence. International Small Business Journal, 25(5), 479-510.

Raffo, C., Lovatt, A., Banks, M., \& O'Connor, J. (2000). Teaching and learning entreprenuership for micro and small businesses in the cultural industries sector. Education and Training, 42(6), 356365.

Rauch, A., \& Hulsink, W. (2015). Putting Entrepreneurship Education Where the Intention to Act Lies: An Investigation Into the Impact of Entrepreneurship Education on Entrepreneurial Behavior. Academy of Management Learning \& Education, 14(2), 187-204.

Rasmussen, E.A., \& Sørheim, R. (2006). Action-based entrepreneurship education. Technovation, 26, 185-194.

Roy, N., Schlosser, F., \& Pasek, Z. (2020). Stimulating entrepreneurial interest in Engineers through an experiential and multidisciplinary course collaboration. Entrepreneurship Education and Pedagogy, 3, 14-40.

Schmidt, J.J., \& Molkentin, K.F. (2015). Building and Maintaining a Regional Inter-University Ecosystem for Entrepreneurship: Entrepreneurship Education Consortium. Journal of Entrepreneurship Education, 18(1), 157-168.

Shane, S., \& Venkataramam, S. (2000). The promise of entreprenuership as a field of research. Academy of Management Review, 25(1), 217-226

Solomon, G.T., Duffy, S., \& Tarabishy, A. (2002). The state of entreprenuership education in the United States: A nationwide survey and analysis. International Journal of Entrepreneurship Education $1(1), 1-22$.

Solomon, G.T. (2007). Examination of entreprenuership education in the United States. Journal of Small Business and Enterprise Development, 14(2), 168-182.

Souitaris, V., Zerbinati, S., \& Al-Laham, A. (2007). Do entrepreneurship programmes raise entrepreneurial intention of science and engineering students? The effect of learning, inspiration and resources. Journal of Business Venturing, 22(4), 566-591.

Takyi-Asiedu, S. (1993). Some socio-cultural factors retarding entrepreneurial activity in sub-Saharan Africa. Journal of Business Venturing, 8(2), 91-98.

Tamásy, C. (2006). Determinants of regional entrepreneurship dynamics in contemporary Germany: A conceptual and empirical analysis. Regional Studies, 40(4), 365-384.

Ulvenblad, P., Berggren, E., \& Winborg, J. (2013). The role of entrepreneurship education and start up experience for handling communication and liability of newness. International Journal of Entrepreneurial Behaviour and Research, 19(2), 187-209.

Unger, J.M., Rauch, A., Frese, M., \& Rosenbusch, N. (2011). Human capital and entrepreneurial success: A meta-analytical review. Journal of Business Venturing, 26(3), 341-358.

Usman, L. (2009). Adolescent street boy urchins and vocational training in northern Nigeria. Diaspora, Indigenous and Minority Education, 3(3), 175-190. 
van der Sluis, J., van Praag, M., \& Vijverberg, W. (2005). Entrepreneurship selection and performance: A meta-analysis of the impact of education in developing economies. World Bank Economic Review, 19(2), 225-261.

Vanevenhoven, J., \& Liguori, E. (2013). The impact of entrepreneurship education: Introducing the entreperneurship education project. Journal of Small Business Management, 51(3), 315-328.

von Graevenitz, G., Harhoff, D., \& Weber, R. (2010). The effects of entrepreneurship education. Journal of Economic Behavior and Organization, 76(1), 90-112.

Walter, S., \& Block, J. (2016). Outcome of entrepreneurship education: An institutional perspective. Journal of Business Venturing, 31, 216 - 233.

Walter, S.G., \& Dohse, D. (2012). Why mode and regional context matter for entrepreneurship education. Entreprenuership and Regional Development, 24(9-10), 807-835

Wilson, F., Kickul, J., \& Marlino, D. (2007). Gender, entrepreeurial self-Efficacy, and entrepreneurial career intentions: Implications for entrepreneurship education. Entrepreneurship Theory and Practice, 31(3), 387-406.

Zanello, G., Fu, X., Mohnen, P., \& Ventresca, M. (2016). The creation and diffusion of innovation in developing countries: A systematic literature review. Journal of Economic Surveys, 30(5), 884912.

Zaring, O., Gifford, E., \& McKelvey, M. (2019). Strategic choices in the design of entrepreneurship education: An explorative study of Swedish higher education institutions. Studies in Higher Education, DOI: 10.1080/03075079.2019.1637841 